\title{
THE ROLE OF THE PIECHCIN CENTRE IN THE DEVELOPMENT OF SPECIALISED TOURISM WITH a VIEW TO DIVER PREPARATION FOR PENETRATION OF THE BaLtic SEA
}

Jolanta Cichowska, Jerzy K. Garbacz, Jerzy Ciechalski

The Jan and Jędrzej Śniadeccy University of Science and Technology in Bydgoszcz, Poland

\section{ABSTRACT}

This work is a preliminary pilot research aiming at defining the role of the Piechcin Diving Centre in the development of specialised tourism. Particular attention was paid to the various elements defining the quality of the services offered. The key aspects and reasons for which respondents visit the centre were also determined. Both the customer's expectations of the organiser of this form of recreation were analysed, and research was made to help understand whether the time the customers spends at the centre facilitates a positive decision regarding the participation in diving trips in larger bodies of water, with particular consideration of the Baltic Sea. Different forms of cooperation between the centre and regional authorities in terms of promoting the region were also reviewed.

Keywords: qualified tourism, recreation, diving safety, competitiveness.

ARTICLE INFO

PolHypRes 2018 Vol. 63 Issue 2 pp. 51 - 61

ISSN: 1734-7009 elSSN: 2084-0535

DOI: $10.2478 / p h r-2018-0013$

Pages: 9, figures: 1, tables: 2

page www of the periodical: www.phr.net.pl

Publisher

Polish Hyperbaric Medicine and Technology Society
Original article

Submission date: $13.12 .2017 \mathrm{r}$.

Acceptance for print: 15.02.2018 r. 


\section{INTRODUCTION}

In recent years, a dynamic development of underwater training and tourism services has been observed in Poland. Diving has become an attractive form of recreation, not only serving active leisure, but above all, the development of people's interests and raising the standard of living. It is the most specialised form of active tourism, which, as Mokras-Grabowska [1] points out, requires from people practising it proper psychophysical preparation, autonomy, being inured to hardships, having impeccable tourism culture, as well as the ability to use tourist equipment. The author adds that the fundamental element of qualified tourism is also the passion of its participants and practising a particular activity with expertise, which results from the involvement both into the discipline and the passion associated with practising tourism itself.

The aim of the study is to present the Piechcin diving centre as an example of the highest form of tourist specialisation. It was important to recognise how the centre is logistically prepared for the organisation of diving recreation, and whether it provides its visitors with safety and comfort. Based on research conducted among individuals using the services of the facility, the role of the Diving Centre was established as a training centre preparing people for penetration of the Baltic Sea waters. The kinds of diving activities which are the most popular among potential recipients were analysed, as well as types of courses and training in which they are most likely to participate. The work presents the expectations of visitors towards the service provider, and the importance of confidence as a factor influencing the establishment of good relations between the organiser and the consumer. The aspect of product creation and development was emphasised in the context of raising competitiveness in rural areas.

\section{MATERIAL AND METHODS}

The research was conducted by means of a diagnostic survey (using an interview questionnaire) on a pilot group of 70 people visiting the Piechcin centre in 2017. The questionnaire consisted of 23 questions mainly with a closed formula. The issues addressed in it concerned:

1. assessment of the role of the centre in preparation for diving in larger bodies of water,

2. diagnosing the main aspects that divers visiting the Diving Centre appreciate and the reasons why they chose it,

3. expectations as to how the organiser should develop the surface and underwater infrastructure,

4. determining whether a good or bad experience during the visitors stay has a bearing on the choice of this form of recreation in the future.

The questionnaire contained a section with the respondent's particulars where the respondents provided data regarding their age, gender and place of residence. It was prepared in such a manner as to obtain, apart from the answers regarding the assessment of the diving centre, additional information on how many times the respondents decided to visit it (and with whom), and where they found information about it. The information on sources from which the respondents learned about the service plays an important role in the research process, as it may affect overall satisfaction with the product, while at the same time cause reduced expectations in relation to it.

To achieve the objective of the study, individuals who had previously had direct contact with diving were taken into account, thus those who already had certain knowledge about underwater tourism, and were therefore able to assess the Piechcin centre against other competing centres in the country. The questionnaire was prepared for respondents in such a way as to enable them to complete it themselves. In the end, 56 questionnaires were analysed as the remaining research material was incomplete and thus unsuitable for the study. The collected statistical data were extended with the methods of analysis and description.

\section{RESEARCH RESULTS AND DISCUSSION}

The study involved $89.2 \%$ of men, which means that they were the dominant gender among the diving enthusiasts. The respondents mainly represented the following three age groups: $35-39$ years $(34.7 \%), 40-44$ years $(19.5 \%)$ and $30-34$ years $(15.2 \%)$. They came from urban centres (92.8\%), mainly cities with the population of over 151 thousand residents (55.1\%). When analysing their level of education, there is a clear advantage of individuals with higher $(49.1 \%)$ and middle education (43.6\%). The Piechcin Diving Centre enjoyed the greatest interest among people living permanently in the following provinces: Wielkopolskie (43.7\%), Kuyavian-Pomeranian (25.4\%), and Łódzkie (12.7\%). The remaining respondents (18.2\%) came from the Pomeranian, Mazovian, West Pomeranian and Lower Silesian regions (they constituted respectively 7.3\%, 5.4\%, 3.7\%, 1.8\% of the total of surveyed persons). The average distance of the place of residence of the respondents from the diving centre was $135 \mathrm{~km}$.

Research revealed that divers knew the reservoir in Piechcin before it was transformed in 2011 into the Diving Centre, as already in the years 2000-2010 they came here for recreational purposes. The data show that the respondents had been visiting the centre mainly since 2015 (69.9\%), and the average number of their arrivals up to 2017 is 21 . Year after year this flooded limestone quarry (located in the Barcin commune in the Kuyavian-Pomeranian Province) is visited by a vast group of divers. As the quarry varies in depth, divers benefit from access to both shallow and deeper parts - the deeper areas having walls that drop vertically to $25 \mathrm{~m}$, allowing for dives regardless of level of training.

The organiser emphasises that the artificial lake, surrounded by white lime rocks contrasting with the azure water, provides guests with an unforgettable, unique experience and allows them to experience conditions similar to being in the "Adriatic" or "Mediterranean"[2].

The advantage of the reservoir is also the varied ichthyofauna (pike, perch, carp, tench, crucian carp, roach, crayfish) and underwater and shore vegetation. Very often once the extraction of raw material is stopped 
such reservoirs, as is emphasised by Majgier et al. [3], are a dissonance with the surrounding landscape. Their revitalisation towards sports and recreation creates an opportunity not only for their new quality but also provides an opportunity to activate regions that have thus far not been considered attractive. Nita [4] adds that quarries require individual treatment. The Piechciński reservoir is a great example of a specialised tourism product evolving and developing over time (especially since 2007, when it was in possession of another operator, namely the SEE Explorer Foundation). Its history dates back to 1860 and is described on the official website of the Barcin Commune, which while promoting it as a place that is worth visiting, does not provide information regarding its current development and functions.

For both parties, namely the organiser of the centre and the local government decision-maker with regard to these areas, this issue should be important, because the commune, due to the natural and tourist values of the area, such as the prepared tourist and walking routes, could retain (with good advertisement) a certain percentage of the large number of visitors to the Diving Centre who visit each year, and thus generate income for its residents, related to, inter alia, renting of rooms, accommodation units or broadly understood services, including catering. Such cooperation would be desirable and positively perceived by local communities.

The Diving Centre is commonly visited by divers once or twice in all seasons of the year (table 1), with a slight advantage of arrivals in winter (mainly one-'s day). The opinion on the availability of the reservoir over the whole year has been positively reviewed, as evidenced by the very good (78.5\%) and good (19.6\%) ratings offered by visitors. Only one person did not have an opinion on this subject, which could be dictated by a one-off stay in the centre or lack of interest in its market offer. Many service users would like to visit Piechcin more often, however it is difficult due to the large distance of the reservoir from their place of residence $(37 \%)$ and a lack of time $(34.7 \%)$. In individual cases, it was stated that these restrictions are also dictated by business trips, work, high service prices, lack of a partner for joint dives, choosing other reservoirs in order to diversify the trips, inadequate depth of the reservoir, as well as adverse opening hours from Monday to Friday $(28.3 \%$ of responses in total). In the last case, however, the organiser informs that individual notifications are taken into account whereby it is possible to adjust the entry to the centre outside the weekly period (9.00-4.00). However, this requires prior arrangement by phone or email.

Respondents indicated that in the Piechcin reservoir they undertake diving activities of mainly tourist (83.6\%), training (60\%) and educational $(36.3 \%)$ character - 20 respondents on average took part in 4 trainings). $27.2 \%$ of individuals participated in night dives, and the objective of $21.8 \%$ of subjects consisted in taking underwater photos or performing photo shooting sessions. A small group, $18.1 \%$ preferred ice-diving, and $7.2 \%$ were interested in a typical familiarisation with the area. The body of water enables performing dives in an underwater training ground ensuring the presence of proper equipment (ropes, buoys) and training platforms placed at various depths.

The number of visits to the Piechcin Diving Centre during particular months of the year. Source: own study on the basis of the survey.

\begin{tabular}{llcccc}
\hline No. & Arrivals at the Diving Centre & $\begin{array}{c}\text { Winter } \\
\text { (XII-II) }\end{array}$ & $\begin{array}{c}\text { Spring } \\
\text { (III-V) }\end{array}$ & $\begin{array}{c}\text { Summer } \\
\text { (VI-VIII) }\end{array}$ & $\begin{array}{c}\text { Autumn } \\
\text { (IX-XII) }\end{array}$ \\
\hline 1. & once a week & 6 & 2 & 2 & 7 \\
\hline 2. & twice a week & - & 5 & 6 & 2 \\
\hline 3. & several times a week & - & - & 2 & 1 \\
\hline 4. & once a month & 6 & 5 & 3 & 4 \\
\hline 5. & twice a month & 2 & 3 & 3 & 3 \\
\hline 6. & several times a month & 1 & 2 & 6 & 4 \\
\hline 7. & once or twice per season & 17 & 14 & 17 & 17 \\
\hline 8. & once a year & 13 & 1 & 1 & 2 \\
\hline \multicolumn{7}{r}{ Total* } & 45 & 32 & 40 & 40 \\
\hline
\end{tabular}

*responses do not sum up due to possibility to provide various answers.

The reasons why respondents decide to come to the Piechcin centre are related to training purposes (raising one's own qualifications - 54.5\%, expanding one's knowledge - 30.9\%, training - 29\%), social aspects (wanting to spend time with acquaintances - 54, 5\%, or friends - $36.3 \%$ ) and typically tourist reasons (49\%). A large group of divers want to break away from everyday life $(52.7 \%)$ and rest in the bosom of nature $(25 \%)$. $21.8 \%$ of the respondents go there for entertainment, and $9 \%$ to take advantage of on-site events (e.g. during Halloween). Divers rarely go to Piechcin alone (8.9\%), or accompanied by family members $(7.1 \%)$ or a spouse $(1.7 \%)$. Most often they are accompanied by friends $(60.7 \%)$, or acquaintances associated with clubs or groups (42.8\%), sports clubs (12.5\%) and tourist groups $(16 \%)$. One person reported having visited the centre with trainees. Nobody, however, indicated a stay with children, which may be dictated by lack of dedicated recreational infrastructure (a playground). It was mentioned as a convenience expected from the centre's organiser to enable visiting the centre in the future with the family.

The majority of the respondents found out about the centre from friends or acquaintances (60\%). One respondent learned about the centre from the family, and $27.7 \%$ obtained the information on the centre from the Internet. The remaining subjects declared that they discovered the place themselves; they knew the reservoir 
before the centre was established, or it was selected by the diving instructors that trained them (a total of 10.8\% of people).

The respondents highly value the Diving Centre first of all for the whole-year character of the service offered $(66 \%)$, safety $(48.2 \%)$, good shore infrastructure (44.6\%), pleasant atmosphere (39.2\%) and diversified underwater infrastructure (33.9\%), which makes the underwater experience more attractive (Figure 1). Under the water one may see standing trees; a 12-meter sea yacht (concrete ship) with a high mast and sail $(14 \mathrm{~m})$; a wooden 5.5 -meter cabin sailboat; a small three-meter high cave and a rock arch, or a dozen sunken mirrors. These are just a few of the attractions whose list is constantly being extended (depending on the needs) on the resort's official website. The organisers' high qualifications (17.8\%) as well as their creativity $(14.2 \%)$ constituted aspects earning fewer points, which does not necessarily mean that they are insufficient.

The first three indications inform that divers wish to be autonomous in terms of the time spent on the implementation of their passion in comfortable conditions. The centre offers them the possibility to follow their priorities. Subsequently, the subjects pointed to training at various levels and qualifications as being important $(8.9 \%)$, as well as the clarity of the water of the Piechcin reservoir (3.5\%).
It is worth noting that in the autumn the transparency of the water reaches up to $15 \mathrm{~m}$, whereas in the winter the visibility reaches up to $20 \mathrm{~m}$ under the ice. In general, the respondents consider diving as a safe activity ( $62.2 \%$ - definitely yes), nevertheless $32 \%$ of the respondents' responses showed some fluctuations, as some of them marked the answer "rather yes". There were only 2 indications in the questionnaire recognising this kind of recreation as definitely dangerous. One person found it difficult to provide an answer to this question as their adventure with diving was quite new. Following their stays in the Piechcin centre, the respondents described the level of their preparation for future dives as very good (42.6\%) and good (34\%). It was rated as average by $6.4 \%$ of respondents, whereas to $17 \%$ of subjects it was difficult to comment on. In turn, for $66 \%$ (37) of all respondents, the stay at the Diving Centre helped in their preparation for performing dives in larger bodies of water. However, only 25 people reported which specific body of water they were referring to. They commonly indicated the Baltic (11) and the Mediterranean Sea (9). Moreover, the respondents mentioned the Arabian Gulf, the South China Sea, the Red Sea, the Black Sea, the Norwegian Sea, Polish lakes (e.g. Lake Hańcza), as well as German, Czech and other similar quarries.
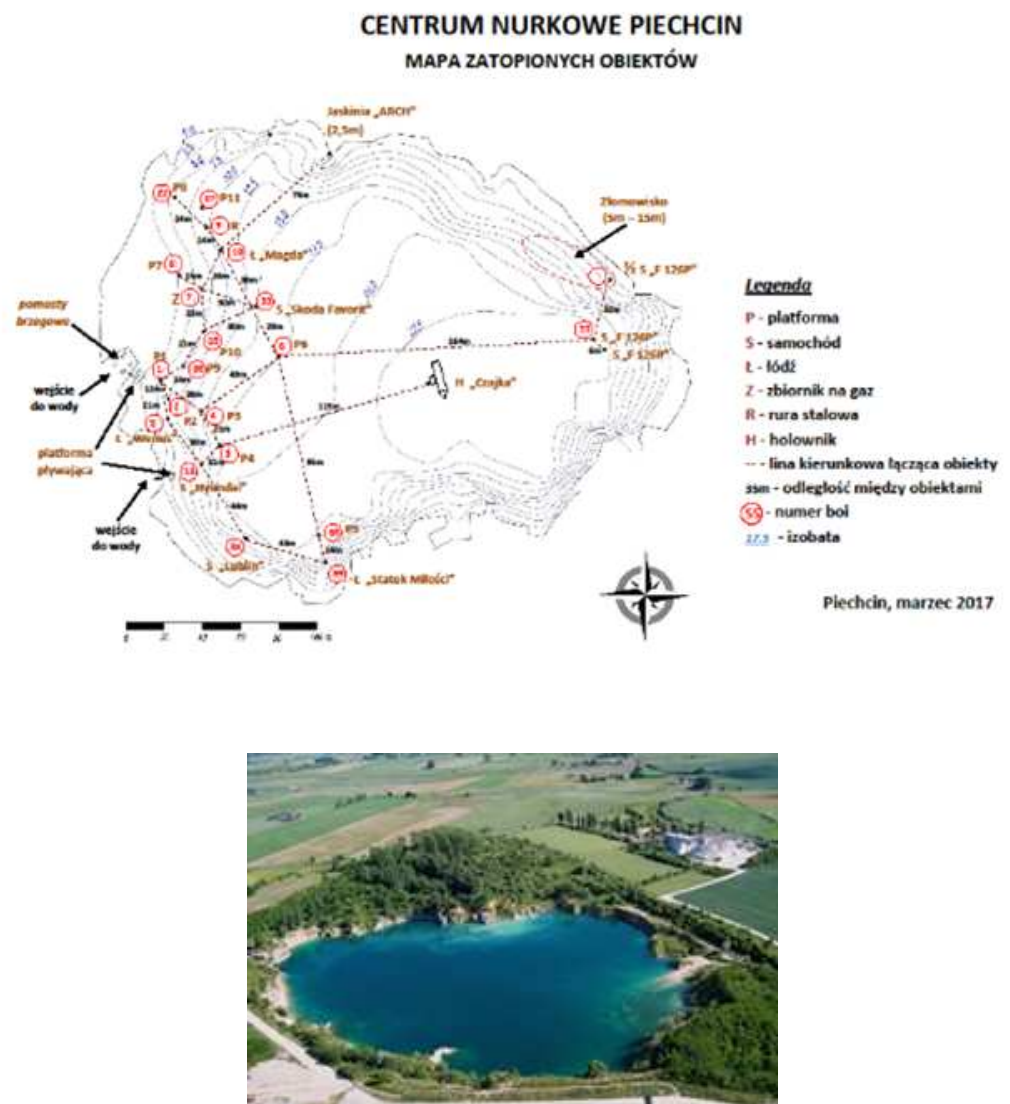

Fig. 1 The site plan of underwater and surface infrastructure of the Piechcin reservoir. Source: the site plan and photograph are presented with the consent of the owner of the Diving Centre. 
Out of the total number of respondents $89.3 \%$ (50) provided answers with regard to infrastructure of the diving centre. According to $48 \%$ of them, it meets their expectations in every respect. Nevertheless, the remaining group of $52 \%$ of people stated that certain improvements should be introduced with regard to the surface and underwater infrastructure. It primarily concerned the installation of signposts under water (e.g. on guardrails), for better orientation in the location of routes, platforms or buoys. Moreover, the respondents suggested an introduction of variations in the form of a "winding tunnel", Halley's bell, or sinking of a boat placed at the shore of the reservoir. More attractive prompts were also requested. In addition, it was pointed out that in the wooden flooring in shelters would be better as the concrete floors caused quick cooling. It was also suggested to use heating in the shelters in order to reduce the unpleasant effect of coldness. At the same time, it was suggested to provide in the area concrete slabs in order to reduce mudding and puddles during rainy weather.

Nevertheless, the underwater attractions themselves were highly appreciated by the respondents (as very good $-46.9 \%$ and good $-46.9 \%$ ), as well as other elements of Diving Centre (tab. 2). Above all, once again they indicated the uniqueness of the atmosphere of the centre $(74.6 \%$ assessed it as very good), the very well prepared social facilities $(71.1 \%)$ and the neatness of the centre and its surroundings $(66.7 \%)$. Again, the respondents highly rated the reservoir's safety $(64 \%$ as very good and $28 \%$ as good), which means that the organiser of this kind of recreation pays close attention to this aspect. The facility is equipped with an AED defibrillator, oxygen kit, medical oxygen and a professional first aid kit. As Wiesner emphasises [5] offering new, exciting water attractions should always go hand in hand with seeking more and more effective forms of security.

A responsible service provider should ensure a high quality of services, the highest quality equipment, recreational devices and reliable performance of duties by the staff. The author adds that the greatest hazards emerge where the need to generate profits makes an irresponsible owner of such a centre blind to the superior values - the life and health of people using the reservoir.

The evaluation of basic elements of a stay in the Diving Centre. Source: prepared on the basis of own research.

\begin{tabular}{llcccccc}
\hline No. & \multicolumn{1}{c}{ Elements of evaluation } & Very good & Good & Average & Bad & $\begin{array}{c}\text { Very } \\
\text { bad }\end{array}$ & $\begin{array}{c}\text { I have no } \\
\text { opinion }\end{array}$ \\
\hline \multicolumn{7}{c}{ a total in $\%$} \\
\hline 1. & Social rooms & 71.1 & 25 & 3.9 & - & - & - \\
\hline 2. & Lecture rooms & 44 & 17 & 2.4 & - & - & 36.6 \\
\hline 3. & Parking space & 58.9 & 27.4 & 13.7 & - & - & - \\
\hline 4. & Sanitary facilities & 50 & 30.8 & 9.6 & - & - & 9.6 \\
\hline 5. & Order within the centre and in the & 66.7 & 29.4 & 3.9 & - & - & - \\
& surroundings & & & & & & \\
\hline 6. & Assistance in making reservations & 31.8 & 17 & 2.4 & - & - & 48.8 \\
\hline 7. & Organisation of stays in terms of & 47.7 & 15.9 & 2.3 & 2.3 & - & 31.8 \\
\hline logistics & Equipment storage possibilities & 51.2 & 20 & 2.2 & - & - & 26.6 \\
\hline 9. & Equipment rental possibilities & 43.2 & 25 & 2.3 & - & - & 29.5 \\
\hline 10. & Underwater attractions & 46.9 & 46.9 & 6.2 & - & - & - \\
\hline 11. & Instructors & 29.5 & 13.8 & 4.5 & - & - & 52.2 \\
\hline 12. & Training & 20.5 & 15.3 & 2.6 & - & - & 61.6 \\
\hline 13. & Safety & 64 & 28 & 2 & - & - & 6 \\
\hline 14. & General atmosphere & 74.6 & 21.6 & 1.9 & - & - & 1.9 \\
\hline 15. & Diving events & 23.6 & 21 & 2.6 & - & - & 52.6 \\
\hline 16. & System of promotion & 31 & 16.7 & 7.2 & 2.3 & - & 42.8 \\
\hline 17. & Service price & 29.1 & 48 & 20.8 & - & - & 2.1 \\
\hline
\end{tabular}

The parking space of the centre (58.8\%) along with the facilities for the storage of equipment (51.2\%) received a very good rating. These elements of the infrastructure are very much appreciated by divers, as during their recreation under water they want to have a feeling that their vehicles and equipment are duly protected. Moreover, in addition to the soft descent into the water, there is the possibility to perform descents from platforms floating on the water (with ladders) which are connected to the shore with the use of gangways, and what is also important is the possibility of accessing the shore by vehicles. Good ratings $(48 \%)$ were mainly related to the price paid for admission to the diving centre. The clients realise, however, that it is not exorbitant since they did not indicate it to be it either at a bad or very bad level. It may mean that it is adequate to the presented offer and does not deviate significantly from the offers of competing centres in the country or region.

As identified from the conducted research, the respondents had difficulties in evaluating the training facilities in the centre or training services. A large group of respondents did not have an opinion on this subject (61.6\% and $52.2 \%$, respectively), which could be dictated 
by the fact that they were already holders of certificates of completion of courses on other bodies of water or they came to Piechcin with their own instructors. There was also a significant percentage of individuals (42.8\%) who had no opinion about the centre's promotion system. Nonetheless, the respondents expressed their interest in receiving promotional materials mainly in the form of laminated maps (49\%) and folders or booklets containing maps of the body of water (34.7\% and $6.1 \%$ respectively). Business cards and leaflets were demanded less frequently ( $4.1 \%$ each). Among the additional ideas was the desire to purchase from the organiser hats and $\mathrm{T}$-shirts with printed images related to the centre (2.1\%).

The equipment rented by the owner of the Diving Centre received a very positive rating. In this respect the offering was assessed as very good $(35.9 \%)$ and good (18.9\%). However, the majority of the respondents $(45.2 \%)$ did not have a fixed opinion on this subject as they brought their equipment to the centre or used rented equipment very rarely. Those who have ever had the opportunity to try out the equipment belonging to the owner of the centre stated that it did not have any defects $(82.6 \%)$. There were only 9 people having some reservations. They concerned: a damaged diving mask strap (1), damaged pressure gauge (1) and mouthpiece (2), a problem with an inflator (1), the lack of an o-ring on the first stage of a breathing apparatus (2), as well as an empty or only partially filled diving cylinder (2). Moreover, the centre offers equipment used for ice diving (boards, ropes, ice bolts, harnesses, ice pikes, chainsaws, ice drills, shovels and many others according to demand) and prepares air holes in the requested places on the water (on individual arrangements).

As compared with competing centres in the country, the centre was rated high, as it received very good (58.5\%) and good scores (37.7\%). None of the respondents indicated bad and very bad scores, and 3.8\% of respondents refused to make such a comparison as Piechcin was the only place that they visited for the purpose of practising diving. Since 2013, i.e. since Zawadzki's research in the centre [6], the quality of the services offered has clearly increased. The new solutions and facilities are primarily related to the modernisation of social facilities (11 comfortable and closed shelters), furnishing of lecture rooms and ensuring proper comfort not only for divers, but also for accompanying persons.

In addition to underwater activities, the respondents also value those that are not related to water (except ordinary swimming and swimming in a boat or a canoe $-17.5 \%$ ) offering them an opportunity to relax and spend time together with other participants or friends. In particular, they pointed to places prepared by the organiser where they can light a campfire $(67.5 \%)$ or prepare a barbecue (77.5\%). The respondents also pointed to the possibility to go hiking around the area, jogging, ride on quads and bicycles, participate in shooting competitions, and paintballing games (a total of $30 \%$ of responses). In order to meet different expectations of visitors, the owner prepares diversified special offers to ensure that the time between dives is more attractive. For example, the centre cooperates with the befriended "Shooting Fraternity of Piechcin", so that divers may test their shooting skills at a professional shooting range. Moreover, the centre tries to establish and maintain good contacts with the local community offering accommodation for enthusiasts of underwater expeditions (hotels, private accommodation, agritourism farms). It also provides the possibility of setting up a tent or trailer (camping car) directly by the body of water. These illustrate the organiser's creativity that is highly appreciated by divers as they have assessed the overall organisation of visits to the centre in terms of logistics as very good $(47.7 \%)$. Perhaps this element of the offer (as well as other highly ranked elements) encouraged $92.4 \%$ to declare their return to the centre in 2018 (only 2 respondents stated that they would not visit it and another 2 replied that they do not know whether they would visit the centre again).

To conclude, the development of post-industrial sites varies, however the main goal is to transform the damaged area while maintaining all its assets and defining its new functions (recreational, sporting, cultural and other) [7]. With relatively low financial resources (usually brought in by the owner or lessee) it is not only possible to create an interesting place willingly frequented by divers from Poland and abroad, but also a place generating new jobs for local inhabitants of the area (accommodation base, restaurants, souvenir shops, exhibitions) [6]. The Piechcin Diving Centre is perfectly matched to this trend. It is primarily a well prepared and safe place for underwater escapades (constantly developing) and, above all, it is an example of the highest form of tourist specialisation. It could become an excellent inspiration for interesting solutions in the vicinity of Cracow, where, as Górecki and Sermet [8] report, there is a lack of ideas for the development of quarries, which are an undervalued heritage of the area. Moreover, it must be emphasised that in recent years, diving has become more and more popular among various forms of active tourism and recreation. Those who choose this way of spending their leisure time are often characterised by an appropriate psychophysical preparation, prefer an active and healthy lifestyle, and many of them also aim to overcome their weaknesses [9].

\section{CONCLUSIONS}

The conducted research has provided the basis for formulation of the following conclusions:

1. The Diving Centre plays an important role in the respondents' preparation for diving in larger bodies of water, nonetheless only a more in-depth research work (which is to be carried out with several hundred participants in 2018) will allow to provide an explicit answer to the question whether their future dives will be mainly related to the Baltic Sea.

2. The pilot study has confirmed that the shortcomings in the infrastructure of the centre as well as the economic criterion are not decisive when it comes to the respondents' choice to revisit it in the future.

They showed an interest in visiting the centre again and, first of all, appreciate the safe conditions and friendly atmosphere created by the owner of the facility. Such a reception of the centre may result from the organiser's entrepreneurial and creative attitude noted by the respondents, which is visible in the gradual improvement of the quality of services provided. 
3. The weakness of the examined entity is its limited involvement/cooperation with the municipal authorities in promoting common products. In contrast to the reported positive relationship on the organiser-consumer line, the establishment of the relationship with local government authorities needs improvement. Its strengthening could bring mutual benefits and help promote and popularise the commune in the region as well as in the country.
4. The centre in Piechcin takes into account the needs of its visitors and is an excellent example of a specialist tourism product that may serve as a model to other similar entities offering recreational and training activities for divers.

\section{REFERENCES}

1. Mokras-Grabowska J: The variety of theoretical methods and approaches to active tourism; (ed.) B. Włodarczyk, Research on tourism. One goal, different approaches; Warsztaty z Geografii Turyzmu, vol. 6 2015, pp. 117-129, ISBN 978-83-7968-831-8;

2. www.bazapiechcin.eu;

3. Majgier L., Badera J. Rahmonov O: Quarries in the Silesia Voivodeship as touristic-recreational facilities in industrial areas; Reacreational landscapes-shaping, use, transformation. Problemy Ekologii Krajobrazu vol. XXVII 2010, pp. 267-275, ISSN 1899-3850;

4. Nita J: Quarries in landscape and geotourism; Dissertations of the Cultural Landscape Commission No. 14, Komisja Krajobrazu Kulturowego PTG, Sosnowiec 2010, pp. 243-251, ISSN 2391-5293;

5. Wiesner W: Multi-agent responsibility for a tragic accident in water; Polish Hyperbaric Research 3(60) 2017 pp. 65-75, ISSN 1734-7009;

6. Zawadzki D: The use of flooded quarries and pit lakes in skilled tourism-recreational diving; Recent problems of geography, Selected problems of geography of tourism, Wydawnictwo Naukowe Uniwersytetu Szczecińskiego 2013, pp. 255-267.

7. Bąbalska A., Musielińska R., Śliwińska-Wyrzychowska A., Bogdanowicz M., Witkowska E: The educational role of former „Lipówka” quarry in Rudniki near Czestochowa; Dissertations of the Cultural Landscape Commision No. 26 2014, pp. 57-56;

8. Górecki J., Sermet E: Quarries of Krakow - an underestimated heritage; Dzieje górnictwa-element europejskiego dziedzictwa kultury 3 (ed. P.P. Zagwożdżon and M.Madziarz) 2010, pp. 123-138;

9. Kisiel M: Diving as a form of active tourism and its effect on natural environment; Wczoraj, dziś i jutro turystyki aktywnej i specjalistycznej 2015, pp. 103-115, ISBN 978-83-7005-586-8.

dr Jolanta Cichowska

Uniwersytet Technologiczno-Przyrodniczy im. Jana i Jędrzeja Śniadeckich w Bydgoszczy,

Katedra Ekoinżynierii i Fizykochemii Środowiska

ul. Sucha 9, 85-789 Bydgoszcz

Tel. (52) 3408261

jolanta.cichowska@utp.edu.pl 